\title{
Commitment to the goal of completing studies in higher education: Dropout risk of the students from social science specialization from three Romanian public universities*
}

\author{
ADRIAN HATOS** and ADRIAN POP \\ Doctoral School of Sociology, University of Oradea, Oradea, Romania \\ (Received: July 9, 2018; accepted: October 18, 2018)
}

\begin{abstract}
This paper is aimed at finding the degree of commitment to the goal of completing studies in higher education of students in the institution they are registered in. The study relies on a questionnaire-based survey, which was applied to students enrolled in the PractiPASS project. The questionnaire was applied to students from the University of Oradea, University of Bucharest, and "Aurel Vlaicu" University from Arad. The analysis was carried out starting from theoretical models from papers, which had studied the same subject. The most important variables that were used for analysis are student's integration (social and academic), financial resources, socioeconomic background, organizational climate, specialization, etc. Using these variables, we tried to find differences between the levels of engagement of students from the three universities, and to find out some of the causes of dropping out.
\end{abstract}

Keywords: commitment to the goal; school dropout; academic integration

\section{INTRODUCTION}

The project Practical learning programme for students "Child protection - From theory to practice" (PractiPASS) was an endeavor of improving service-learning that included as target group students from three public universities from Romania: The University of Oradea (as lead partner), University of Bucharest, and University "Aurel Vlaicu" from Arad. In each of the three universities involved in the project, the participants were students at bachelor and master level in social sciences: mainly social work plus smaller contingents of students in psychology, sociology, pedagogy, and related master program.

The project involved, among other things, monitoring students' engagement through surveys with the target group in which various items measuring commitment to the educational program in which the subject was enrolled as well as to the activities and the targets of the project were assessed. According to the results of the first survey (January-March 2012), conducted with the students participating in the project $(N=498)$, the subjective likelihood of school dropout is significantly higher in case of students from the University of Oradea. Motivated by the practical interest of ensuring a high level of engagement for students and a low student enrollment fluctuation and the scientific one, of explaining the significant variations regarding the commitment to educational objectives in similar conditions, we considered useful to investigate the correlations of the subjectively self-assesesed risk of dropping out in the case of the students from the Faculty of Social Sciences of the University of Oradea, compared with the situation at the other two universities participating in the PractiPASS project. If we take as reference the University of Arad, Oradea University students have a two times higher perceived risk of dropping out compared with their colleagues from Arad (Table 1). The motivation of this paper becomes immediately clear as dropout is one of the most challenging issues faced by Romanian universities (Bechir, 2017) and service-learning is expected to contribute to increase persistence (Kuh, Kinzie, Buckley, Bridges, \& Hayek, 2006).

\section{THEORETICAL MODEL}

Clearly, the question that generated the analyses of these pages "Have you thought about abandoning the current study program without having acquired a degree?" does not directly measure the risk of dropout or the intention of abandoning, even though it is related to these concepts. Cross-sectional studies, which cannot actually study dropout as dependent variable, analyze indicators of the so-called

*The first version of the article was published in Annals of the University of Oradea, series Sociology-Social Work, Vol. 11 (2012), pp. 5-16. Reprinted with permission. Project Practical learning programme for students "Child protection - From theory to practice" was implemented between 2010 and 2013 with financial support from the European Union through the European Social Fund, project code POSDRU/90/2.1/S/61957.

** Correspondence: Adrian Hatos, Doctoral School of Sociology, University of Oradea, Strada Universităţii nr. 1, Oradea, Romania; Phone/Fax: +40 259 408293; e-mail: ahatos@uoradea.ro

This is an open-access article distributed under the terms of the Creative Commons Attribution 4.0 International License, which permits unrestricted use, distribution, and reproduction in any medium, provided the original author and source are credited, a link to the CC License is provided, and changes - if any - are indicated. (SID_1) 
Table 1. Have you thought to abandon the current course of study program having acquired a degree? (\%)

\begin{tabular}{lcr}
\hline & No & Yes \\
\hline University of Arad & 85.8 & 14.2 \\
University of Bucharest & 90.2 & 9.8 \\
University of Oradea & 74.8 & 25.2 \\
\hline
\end{tabular}

dropout syndrome, which is indicated by discussions about abandonment and intention to drop out (Bean \& Metzner, 1985; Bennett, 2003). On the other hand, the question used in our research operationalizes the concept of commitment to successfully fulfill a study program (goal commitment), which itself is considered as an important predictor of persistence or, conversely, of dropout from education system. In the following, we will use for comfort, the short-term commitment to the goal, with the restricted sense of commitment to the goal of completing the current course of study.

The importance of initial commitments to long-term persistence in college and success in finalizing the study cycle had been recognized in all theories about dropout from higher education. This explains the fact that commitment to the goal has been investigated in many researches dedicated to the issue of dropping out. The results of these studies have emphasized the importance of commitment to the objective of a successful academic journey (Farabaugh-Dorkins, 1991; Munro, 1981).

In order to explain variation in commitment to the goal of degree completion, narrowly understood as described above, we have formulated following the relevant literature three alternative explanations that refer to three categories of predictors of school engagement based on the well-known theories regarding student persistence in higher education: Tinto's integralist model (1993), the rational choice model (Becker, 1975; Chen, 2008; Manski \& Wise, 1983), and Morgan's commitments model (Morgan, 2005). In brief, we argue that goal commitment is correlated with the student's academic and social integration, with background socioeconomic features that describe the student as traditional or non-traditional and with indicators of resources important for completion of studies.

\section{Students' academic and social integration}

Tinto's model, which is well-known in the area of studies about persistence in higher education, is called "integralist" because it highlights the importance of student integration in academic and social processes of the institution in which they are enrolled, in their decisions to continue or discontinue studies, where the commitment to the goal is a mediator of the relationship between integration and dropout. Tinto's model highlights (pp. 84-137) that, in order to develop strong commitment to objective of completion studies, students must be integrated both socially - having positive relationships with peers or teachers and researchers, and academically, which is indicated by positive adaptation to the requirements of the educational institution (Pusztai, 2011). The dimensions of academic and social integration used in the current research are the evaluations of school climate and student satisfaction. Some of the important relationships presumed in the integralist model of student persistence are those of social and academic integration on one hand, and students commitment to the goal on the other hand. To this model that largely confirm in their studies, Pascarella and Terenzini (1980) add the importance of the relationships that the students develop with faculty.

\section{Traditional students versus non-traditional students}

The fact that traditional and non-traditional students differ in their commitment to goal completion is theoretically a plausible hypothesis, because we know from previous research that traditional students (young people, who usually started college immediately after high school) have stronger attachments to the goal of successful completion of studies, primarily but not exclusively, because they have better resources and less disincentives and, therefore, also lower dropout rates (Bean, 1985; Farabaugh-Dorkins, 1991; Lassibille \& Gómez, 2007; Lohfink \& Paulsen, 2005; Pascarella, Pierson, Wolniak, \& Terenzini, 2004; Wardley, Bélanger, \& Leonard, 2013). In consonance with the literature, the main indicator of belonging to one category or another of students is represented by the interruption of studies before the current education cycle for a minimum period of 1 year. However, the issue of resources deserves a special focus.

\section{The impact of resources}

Since attending university comes with costs, both direct and indirect impacts of economic factors on student persistence have often been investigated in the works in this area. Chen (2008) explored, for example, the impact of financial aid on dropout and concluded that scholarships and grants mediate in a significant degree the effect of academic performance and commitment on the decision to dropout. In this paper, we will also investigate whether grants, funding mode (tuition fee paying or tuition fee exempt) availability, or existence of his/her own money (wages) influence commitment to the objective in the way predicted by theory (Breier, 2010), namely, that as the pressure of the material resources is greater the commitment to the goal decreases.

On the other hand, available time is another resource necessary to overcome successfully most academic tasks. It is plausible to expect that people who have concurrent tasks to show low commitment to their studies. Therefore, we investigate the most important way in which such commitments - as marriage and having a job - affects commitment to the goal for students of the three universities involved in our research (Bean, 1985; Pearson, 2004).

Each university has participated with students of Social Work specialty, to which were added, in the target group, students from other specialties (Psychology, Sociology, Special Education, and Master's programs). It is possible that the intention of dropout to be more common in the case of students enrolled in some specialties, and to that the disadvantage of the University of Oradea students because of the specific composition of student population of certain specializations. Introducing the indicators of university, cycle of studies (BA or MA and study program) is therefore necessary in subsequent analyses. 


\section{VARIABLES}

\section{Dependent variable}

Commitment to the goal is the result of recoding into two categories the answers to the question which asked students how often they thought about abandoning current studies without obtaining a degree. About $15.7 \%$ of the students have thought at least once to abandon their courses.

\section{Independent variables}

All the structural variables have been dichotomized to facilitate analysis, that is, to reduce the degrees of freedom in the logistic regressions. Distributions are presented in Table 2.

\section{Socioeconomic background}

University and study cycle: Arad, Bucharest, and Oradea. In subsequent logistic regression models, we dichotomized the affiliation to university by building two categories corresponding to universities in Bucharest and Oradea (the one from Arad remains for reference). In absolute numbers, distribution per universities is as follows: 176 at the University of Arad, 183 at the University of Bucharest, and 139 at the University of Oradea. Regarding the study cycle, all students are in first or second years of Bachelor cycle and first year of MA cycle. The Master students are only from the University of Oradea.

\section{Organizational climate}

Organizational climate indicators were also dichotomized noting with 1 for the students who said good and very good relationships with teachers and those who were satisfied and very satisfied with the university (see Table 3).

To test the explanations suggested above, we modeled in blocks, using logistic regression and the dependent variable. In Block 1, we introduced the corresponding variables of

Table 2. Distributions of sociodemographic variables

\begin{tabular}{lc}
\hline & \% for 1 \\
\hline Gender (male =1) & 7.8 \\
Marital status (married or divorced =1) & 6.8 \\
Employment status (employed = 1) & 19.5 \\
With scholarship (scholarship = 1) & 20.1 \\
Funding of education (tuition-free student $=1$ ) & 56.2 \\
Father's level of education (father with tertiary & 20.9 \\
$\quad$ education level =1) & \\
\hline
\end{tabular}

Table 3. Distribution of organizational climate items

\begin{tabular}{lc}
\hline & $\%$ for 1 \\
\hline $\begin{array}{l}\text { Relationships with teachers (good relationship } \\
\text { with teachers }=1 \text { ) }\end{array}$ & 92.8 \\
$\begin{array}{l}\text { Satisfaction with the learning conditions (satisfied } \\
\text { and very satisfied }=1 \text { ) }\end{array}$ & 88.0 \\
\hline
\end{tabular}

the university and the year/cycle of study; in Block 2, we introduced the socioeconomic variables, and in Block 3, we introduced the school climate variables.

\section{RESULTS OF THE MULTIVARIATE MODELS}

\section{Block 1: University and study cycle}

The model from the Block 1 shows that study cycle does not matter for the declared intention of dropout but only the university. Having the University of Arad as referent, being student at University of Oradea doubles the risk of intention to abandon. The results show that at least the cycle of study does not determine the risk of intention to dropout (Table 4).

\section{The test of effect of specializations}

It is true that the intention of dropout is more common in some specializations than others. Table 5 shows that it is much higher for MA students than in the case of BA students, and higher for students in sociology, for instance, than for students in social work. However, comparing by specializations (this is possible for Social Work, Sociology, and Psychology due to number of cases) between universities, we find that, consistently, the percentage of those who thought about dropping out at the University of Oradea is higher than in other universities.

On the other hand, we must admit that some of the percentage of students who thought to dropout from the University of Oradea are due to programs toward which students have a low attachment (Special Psycho-pedagogy, MA programs) that are found only at the University of Oradea.

\section{Block 2: Socioeconomic dimension}

None of the independent variables indicating structural features has significant effect on the dependent variable. Instead, the university effect remains significant on edge (Table 6).

\section{Block 3: School climate}

Good relationships with teachers have been reduced by one third the risk of the intention of dropout. Other effects remain unchanged, while that of the University becomes even stronger. This result is important as it shows that the intention of dropout is more common at the University of Oradea because of the university climate (if it would be controlled, via the introduction of the measure of relations with teachers, the university effect should disappear).

These analyses have confirmed a single hypothesis, namely that the intention of dropout depends on the climate, specifically the perceived relationships with teachers, but did not allow us to understand why the risk is higher at the University of Oradea than the other two universities. In each of the three models, the effect of the University of Oradea is significant (Table 7). 
Table 4. Logistic regression model (Block 1)

\begin{tabular}{|c|c|c|c|c|c|c|}
\hline & $B$ & $S E$ & Wald & $d f$ & Sig. & $\operatorname{Exp}(B)$ \\
\hline Cycle & & & 3.887 & 2 & 0.143 & \\
\hline Cycle $=2 \mathrm{nd}$ bachelor year & 0.464 & 0.312 & 2.221 & 1 & 0.136 & 1.591 \\
\hline Cycle $=$ MA & 0.946 & 0.576 & 2.702 & 1 & 0.100 & 2.576 \\
\hline University & & & 8.231 & 2 & 0.016 & \\
\hline University of Bucharest & -0.240 & 0.386 & 0.387 & 1 & 0.534 & 0.787 \\
\hline University of Oradea & 0.678 & 0.326 & 4.329 & 1 & 0.037 & 1.969 \\
\hline Constant & -2.134 & 0.338 & 39.749 & 1 & 0.000 & 0.118 \\
\hline
\end{tabular}

Note. $R^{2}$ Nagelkerke $=.06$.

Table 5. Intention to dropout per university per field of study

\begin{tabular}{|c|c|c|c|c|}
\hline \multirow[b]{2}{*}{ University } & & & \multicolumn{2}{|c|}{ He has thought about dropping out } \\
\hline & & & No $(\%)$ & Yes $(\%)$ \\
\hline \multirow[t]{3}{*}{ UA } & $\begin{array}{l}\text { Which of the following specializations } \\
\text { are you enrolled? }\end{array}$ & Social worker & 85.9 & 14.1 \\
\hline & & Psychology & 85.7 & 14.3 \\
\hline & Total & & 85.8 & 14.2 \\
\hline \multirow[t]{5}{*}{ UB } & Which of the following specializations are & Sociology & 77.8 & 22.2 \\
\hline & you enrolled? & Social worker & 90.6 & 9.4 \\
\hline & & Psychology & 100.0 & \\
\hline & & Another, which? & 100.0 & \\
\hline & Total & & 90.2 & 9.8 \\
\hline \multirow[t]{6}{*}{ UO } & Which of the following specializations are & Sociology & 71.4 & 28.6 \\
\hline & you enrolled? & Social worker & 80.6 & 19.4 \\
\hline & & Psychology & 76.9 & 23.1 \\
\hline & & Special Psycho-pedagogy & 50.0 & 50.0 \\
\hline & & Social services management & 57.1 & 42.9 \\
\hline & Total & & 74.8 & 25.2 \\
\hline
\end{tabular}

Note. UA: University of Arad; UB: University of Bucharest; UO: University of Oradea.

Table 6. Logistic regression model (Block 2)

\begin{tabular}{|c|c|c|c|c|c|c|}
\hline & $B$ & $S E$ & Wald & $d f$ & Sig. & $\operatorname{Exp}(B)$ \\
\hline Cycle & & & 2.689 & 2 & 0.261 & \\
\hline Cycle $=2$ nd year BA & 0.426 & 0.330 & 1.667 & 1 & 0.197 & 1.531 \\
\hline Cycle $=\mathrm{MA}$ & 0.798 & 0.598 & 1.778 & 1 & 0.182 & 2.220 \\
\hline University & & & 7.961 & 2 & 0.019 & \\
\hline UB & -0.228 & 0.437 & 0.272 & 1 & 0.602 & 0.796 \\
\hline UO & 0.726 & 0.372 & 3.805 & 1 & 0.051 & 2.066 \\
\hline Age & 0.023 & 0.033 & 0.474 & 1 & 0.491 & 1.023 \\
\hline Gender $=$ male & 0.100 & 0.468 & 0.046 & 1 & 0.831 & 1.105 \\
\hline Marital $=$ married & -0.476 & 0.708 & 0.452 & 1 & 0.501 & 0.621 \\
\hline Employment $=$ employed & 0.139 & 0.371 & 0.141 & 1 & 0.707 & 1.150 \\
\hline Scholarship $=$ yes & -0.168 & 0.357 & 0.223 & 1 & 0.637 & 0.845 \\
\hline Tax-free $=$ yes & 0.011 & 0.328 & 0.001 & 1 & 0.973 & 1.011 \\
\hline Father with tertiary education $=$ yes & 0.382 & 0.308 & 1.541 & 1 & 0.214 & 1.465 \\
\hline Constant & -2.701 & 0.756 & 12.764 & 1 & 0.000 & 0.067 \\
\hline
\end{tabular}

Note. $R^{2}$ Nagelkerke $=.07$. UB: University of Bucharest; UO: University of Oradea.

\section{Explorations}

To solve this conundrum, we explored the interactions of the dependent variable with certain independent characteristics and got a surprising result, which has the capacity to cover (statistically) the effect of belonging to the university: being a tuition-free student at the University of Oradea determines a dramatic increase of the risk of intending to dropout.

Table 8 clearly shows that in terms of dropout intention conditional on the payment of tuition, students at the 
Table 7. Logistic regression - Block 3 (climate variables added)

\begin{tabular}{|c|c|c|c|c|c|c|}
\hline & $B$ & $S E$ & Wald & $d f$ & Sig. & $\operatorname{Exp}(B)$ \\
\hline Cycle & & & 2.648 & 2 & 0.266 & \\
\hline Cycle $=2$ nd year BA & 0.445 & 0.339 & 1.722 & 1 & 0.189 & 1.560 \\
\hline Cycle $=$ MA & 0.784 & 0.610 & 1.654 & 1 & 0.198 & 2.190 \\
\hline University & & & 8.623 & 2 & 0.013 & \\
\hline UB & -0.036 & 0.451 & 0.006 & 1 & 0.936 & 0.964 \\
\hline UO & 0.896 & 0.390 & 5.287 & 1 & 0.021 & 2.451 \\
\hline Age & 0.022 & 0.034 & 0.430 & 1 & 0.512 & 1.022 \\
\hline Gender $=$ male & -0.013 & 0.480 & 0.001 & 1 & 0.978 & 0.987 \\
\hline Marital $=$ married & -0.585 & 0.737 & 0.631 & 1 & 0.427 & 0.557 \\
\hline Employment $=$ employed & 0.224 & 0.378 & 0.352 & 1 & 0.553 & 1.252 \\
\hline Scholarship $=$ yes & -0.056 & 0.362 & 0.024 & 1 & 0.877 & 0.945 \\
\hline Tax-free =yes & 0.008 & 0.331 & 0.001 & 1 & 0.982 & 1.008 \\
\hline Father with tertiary education $=$ yes & 0.458 & 0.312 & 2.155 & 1 & 0.142 & 1.580 \\
\hline Relationship with teachers good = yes & -1.146 & 0.538 & 4.536 & 1 & 0.033 & 0.318 \\
\hline Satisfied with conditions $=$ yes & -0.527 & 0.405 & 1.690 & 1 & 0.194 & 0.590 \\
\hline Constant & -1.346 & 0.925 & 2.116 & 1 & 0.146 & 0.260 \\
\hline
\end{tabular}

Note. $R^{2}$ Nagelkerke $=.10$. UB: University of Bucharest; UO: University of Oradea.

Table 8. Logistic regression model with interactions

\begin{tabular}{|c|c|c|c|c|c|c|}
\hline & $B$ & $S E$ & Wald & $d f$ & Sig. & $\operatorname{Exp}(B)$ \\
\hline Cycle & & & 3.482 & 2 & 0.175 & \\
\hline Cycle $=2$ nd year BA & 0.581 & 0.344 & 2.846 & 1 & 0.092 & 1.788 \\
\hline Cycle $=$ MA & 0.763 & 0.614 & 1.543 & 1 & 0.214 & 2.144 \\
\hline University & & & 0.016 & 2 & 0.992 & \\
\hline UB & -0.071 & 0.848 & 0.007 & 1 & 0.933 & 0.931 \\
\hline UO & 0.041 & 0.547 & 0.006 & 1 & 0.940 & 1.042 \\
\hline Age & 0.020 & 0.034 & 0.343 & 1 & 0.558 & 1.020 \\
\hline Gender $=$ male & -0.046 & 0.479 & 0.009 & 1 & 0.923 & 0.955 \\
\hline Marital $=$ married & -0.553 & 0.732 & 0.571 & 1 & 0.450 & 0.575 \\
\hline Employment $=$ employed & 0.220 & 0.385 & 0.327 & 1 & 0.568 & 1.246 \\
\hline Scholarship $=$ yes & -0.123 & 0.364 & 0.114 & 1 & 0.735 & 0.884 \\
\hline Tax-free $=$ yes & -1.084 & 0.670 & 2.616 & 1 & 0.106 & 0.338 \\
\hline Father with tertiary education $=$ yes & 0.533 & 0.319 & 2.793 & 1 & 0.095 & 1.704 \\
\hline Relationship with teachers good = yes & -1.143 & 0.543 & 4.437 & 1 & 0.035 & 0.319 \\
\hline Satisfied with conditions $=$ yes & -0.413 & 0.409 & 1.017 & 1 & 0.313 & 0.662 \\
\hline University $\times$ Tuition & & & 5.184 & 2 & 0.075 & \\
\hline UB by tuition (tuition-free $=1$ ) & 0.869 & 1.056 & 0.678 & 1 & 0.410 & 2.385 \\
\hline UO by tuition (tuition-free $=1$ ) & 1.903 & 0.844 & 5.079 & 1 & 0.024 & 6.705 \\
\hline Constant & -1.208 & 0.922 & 1.718 & 1 & 0.190 & 0.299 \\
\hline
\end{tabular}

Note. $R^{2}$ Nagelkerke $=.12$. UB: University of Bucharest; UO: University of Oradea.

University of Oradea and University of Arad show opposite behavior. While tuition-free students from Arad have the lower probability of considering dropping out $(6.4 \%)$, the tuition-free students from Oradea are in the opposite situation, nearly $30 \%$ of them thinking at least once to quit. Concerning the students who have to pay tuition fee, the percentages are similar, but significantly higher than those of the students from University of Bucharest.

Table 9 clearly shows that in terms of dropout intention conditional on the payment of tuition, students at the University of Oradea and University of Arad show opposite behavior. While tuition-free students from Arad have the lowest probability of considering dropping out (6.4\%), the tuition-free students from Oradea are in the opposite situation, nearly $30 \%$ of them thinking at least once to quit.
Concerning the students who have to pay tuition fee, the percentages are similar, but significantly higher than those of the students from University of Bucharest (Fig. 1).

Obviously at this point, the problem becomes: how to explain the low commitment of tuition-free students from the University of Oradea or, conversely, the low attachment of the tax form students from the University of Arad?

In the case of the University of Oradea in a first phase, we thought a possible simple explanation is the fact that many of those enrolled in tuition free form have chosen their specialization based on the economic perspective and have given up their vocational preferences because of the benefit of exemption from payment of fees. This hypothesis is quickly refuted when comparing opinions of students from the specializations of Psychology and Social Work from the 
Table 9. Investigation of interactions

\begin{tabular}{|c|c|c|c|c|c|}
\hline \multirow[b]{2}{*}{ University } & & & \multicolumn{3}{|c|}{ Has thought about dropping out } \\
\hline & & & No $(\%)$ & Yes $(\%)$ & Total $(\%)$ \\
\hline \multirow[t]{3}{*}{ UA } & Tuition & Tuition paying & 82.9 & 17.1 & 100.0 \\
\hline & & Tuition-free & 93.6 & 6.4 & 100.0 \\
\hline & Total & & 85.8 & 14.2 & 100.0 \\
\hline \multirow[t]{3}{*}{ UB } & Tuition & Tuition paying & 91.2 & 8.8 & 100.0 \\
\hline & & Tuition-free & 89.9 & 10.1 & 100.0 \\
\hline & Total & & 90.2 & 9.8 & 100.0 \\
\hline \multirow[t]{3}{*}{ UO } & Tuition & Tuition paying & 80.0 & 20.0 & 100.0 \\
\hline & & Tuition-free & 71.4 & 28.6 & 100.0 \\
\hline & Total & & 74.8 & 25.2 & 100.0 \\
\hline
\end{tabular}

Note. UA: University of Arad; UB: University of Bucharest; UO: University of Oradea.

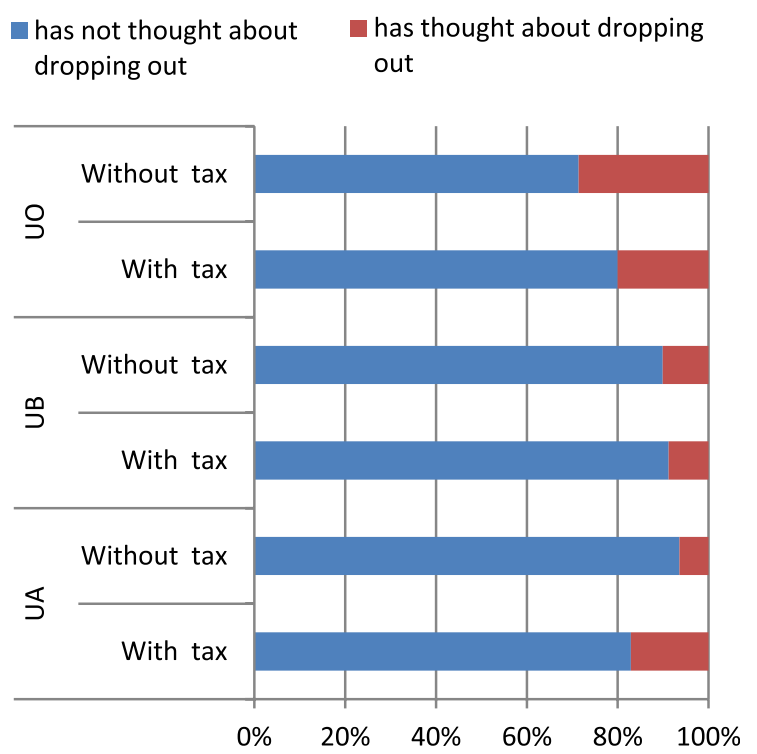

Fig. 1. The intention of dropping out by university and tuition paying

University of Oradea and University of Arad on the one hand, and opinions of students enrolled in Sociology programs at the University of Bucharest and University of Oradea on the other hand.

It is noteworthy that regardless of their specialization (Psychology or Social Work), the contrast between those who pay and those without tuition fee remains even when the comparison between the University of Oradea and University of Arad is made. The situation that contradicts the above hypothesis is that of Psychology specialization because of its strong entrance competition, at least at the University of Oradea, so it is unlikely that those who enrolled in this specialization without having to pay tuition had stronger preferences for another specialization where they could not enter without tax. Concerning the students of Sociology specialization, the numbers are so small that comparisons are less relevant (9 students from the University of Bucharest vs. 21 students from the University of Oradea).

At this point of the analysis, we must admit that we have no other explanation that can be tested. We can speculate, however, that part of the explanation lies in the fact that students of the University of Oradea are in a larger degree "captives" of their university than those from the University of Arad (Table 10). The small distance between Arad and Timisoara allows the best candidates from Arad to enroll in desired specialties in Timisoara without increasing too much the direct costs of schooling. For many gifted candidates from Oradea, there is no such option.

\section{RESULTS}

The main results of this mini-survey tracked the sources of variation of dropout intention of the students involved in the project PractiPASS from the three participating universities:

1. Neither the field of study, nor the educational cycle, nor, especially, the socioeconomic elements that describe student background do explain the intention of dropout. None of the variables in these classes are significant predictors of the indicators of the intention to dropout, whereas the affiliation to the University of Oradea has a consistently strong positive effect on the intention to dropping out.

2. The intention of dropout has one among the few identified covariates the perceived relationship students have with their teachers: as expected, if the relationship students have with their teachers is described in more positive terms, the lower the risk of students thinking about dropping out. Relationships between students and teachers, however, do not explain the variation between universities in terms of intention of abandoning, so we cannot say that, at the University of Oradea, relationships with teachers are of lower quality, which would explain the high frequency of early intention, which we find in this institution.

3. The large share of those who have thought at least once at quitting college at the University of Oradea is covered, in fact, by the unexpected attitudes of students enrolled in the tuition-free form at this institution of higher education: those who are in this situation at the University of Oradea have a six times higher risk than those in the same situation at the "Aurel Vlaicu" University of Arad. This phenomenon is only partially explored in this report, and it appears to be independent of the specialization. Unlike their 
Table 10. The intention of leaving, per university, specialization, and registration form

\begin{tabular}{|c|c|c|c|c|c|c|}
\hline \multirow[b]{2}{*}{ Field of study } & & & & \multicolumn{2}{|c|}{ He has thought about dropping out } & \multirow[b]{2}{*}{ Total $(\%)$} \\
\hline & \multicolumn{3}{|c|}{ University and tuition } & No $(\%)$ & Yes $(\%)$ & \\
\hline \multirow[t]{6}{*}{ Sociology } & UB & Tuition & Tuition paying & 83.3 & 16.7 & 100.0 \\
\hline & & & Without tuition & 66.7 & 33.3 & 100.0 \\
\hline & & Total & & 77.8 & 22.2 & 100.0 \\
\hline & UO & Tuition & Tuition paying & 50.0 & 50.0 & 100.0 \\
\hline & & & Without tuition & 73.7 & 26.3 & 100.0 \\
\hline & & Total & & 71.4 & 28.6 & 100.0 \\
\hline \multirow[t]{9}{*}{ Social work } & UA & Tuition & Tuition paying & 82.9 & 17.1 & 100.0 \\
\hline & & & Without tuition & 91.3 & 8.7 & 100.0 \\
\hline & & Total & & 85.9 & 14.1 & 100.0 \\
\hline & UB & Tuition & Tuition paying & 92.9 & 7.1 & 100.0 \\
\hline & & & Without tuition & 90.2 & 9.8 & 100.0 \\
\hline & & Total & & 90.6 & 9.4 & 100.0 \\
\hline & UO & Tuition & Tuition paying & 85.0 & 15.0 & 100.0 \\
\hline & & & Without tuition & 78.6 & 21.4 & 100.0 \\
\hline & & Total & & 80.6 & 19.4 & 100.0 \\
\hline \multirow[t]{8}{*}{ Psychology } & UA & Tuition & Tuition paying & 83.0 & 17.0 & 100.0 \\
\hline & & & Without tuition & 95.8 & 4.2 & 100.0 \\
\hline & & Total & & 85.7 & 14.3 & 100.0 \\
\hline & UB & Tuition & Tuition paying & 100.0 & & 100.0 \\
\hline & & Total & & 100.0 & & 100.0 \\
\hline & UO & Tuition & Tuition paying & 79.3 & 20.7 & 100.0 \\
\hline & & & Without tuition & 70.0 & 30.0 & 100.0 \\
\hline & & Total & & 76.9 & 23.1 & 100.0 \\
\hline \multirow[t]{3}{*}{ Special Psycho-pedagogy } & UO & Tuition & Tuition paying & 75.0 & 25.0 & 100.0 \\
\hline & & & Without tuition & 33.3 & 66.7 & 100.0 \\
\hline & & Total & & 50.0 & 50.0 & 100.0 \\
\hline \multirow[t]{2}{*}{ Social services management } & UO & Tuition & Without tuition & 57.1 & 42.9 & 100.0 \\
\hline & & Total & & 57.1 & 42.9 & 100.0 \\
\hline \multirow[t]{2}{*}{ Another, which? } & UB & Tuition & Without tuition & 100.0 & & 100.0 \\
\hline & & Total & & 100.0 & & 100.0 \\
\hline
\end{tabular}

Note. UA: University of Arad; UB: University of Bucharest; UO: University of Oradea.

colleagues from Arad (those in Bucharest being situated somewhere in an intermediate position in this matter), students who are enrolled in the tuition-free form of study at the University of Oradea, regardless of specialization, are less attached to the aim of completing their studies than their peers that pay tax. Although, theoretically, belonging to similar structural situations, the students who do not pay tuition at the two universities act apparently different motivating forces. This suggests that economic incentives recorded here as tuition-free education - in higher education enrollment cannot offset the need for intrinsic motivation in the form of following one's vocation, and policies that will intend to direct career choices based on this kind of instruments will determine low goal commitments and large dropout rates. This needs to be explored further though.

Funding sources: Data collected through the POSDRU project: POSDRU/90/2.1/S/61957 "Practice learning for students - Child protection from theory to practice" funded by the European Social Fund.

Authors' contribution: AH contributed $75 \%$ and AP contributed $25 \%$ for this study.

Conflict of interest: The authors declare no conflict of interest.

\section{REFERENCES}

Bean, J. P. (1985). Interaction effects based on class level in an explanatory model of college student dropout syndrome. American Educational Research Journal, 22(1), 35-64. doi:10.3102/00028312022001035

Bean, J. P., \& Metzner, B. S. (1985). A conceptual model of nontraditional undergraduate student attrition. Review of Educational Research, 55(4), 485-540. doi:10.2307/1170245

Bechir, M. (2017). Abandonul în universităţi: Mai mult de unul din trei studenţi nu ajunge la licenţă [Dropout from universities: 
more than one students in three does not graduate]. Curs de guvernare. Retrieved from http://cursdeguvernare.ro/abandonulin-universitati-mai-mult-de-unul-din-trei-studenti-nu-ajunge-lalicenta.html

Becker, G. S. (1975). Front matter, human capital: A theoretical and empirical analysis, with special reference to education. New York, NY: NBER.

Bennett, R. (2003). Determinants of undergraduate student drop out rates in a university business studies department. Journal of Further and Higher Education, 27(2), 123-141. doi:10.1080/ 030987703200065154

Breier, M. (2010). From 'financial considerations' to 'poverty': Towards a reconceptualisation of the role of finances in higher education student drop out. Higher Education, 60(6), 657-670. doi:10.1007/s10734-010-9343-5

Chen, R. (2008). Financial aid and student dropout in higher education: A heterogeneous research approach. In J. C. Smart (Ed.), Higher education (Vol. 23, pp. 209-239). Dordrecht, The Netherlands: Springer.

Farabaugh-Dorkins, C. (1991). Beginning to understand why older students drop out of college: A path analytic test of the Bean/ Metzner model of nontraditional student attrition. AIR Professional File, 39, 13.

Kuh, G. D., Kinzie, J. L., Buckley, J. A., Bridges, B. K., \& Hayek, J. C. (2006). What matters to student success: A review of the literature (Vol. 8). Washington, DC: National Postsecondary Education Cooperative.

Lassibille, G., \& Gómez, L. N. (2007). Why do higher education students drop out? Evidence from Spain. Education Economics, 16(1), 89-105. doi:10.1080/09645290701523267

Lohfink, M. M., \& Paulsen, M. B. (2005). Comparing the determinants of persistence for first-generation and continuing- generation students. Journal of College Student Development, 46(4), 409-428. doi:10.1353/csd.2005.0040

Manski, C. F., \& Wise, D. A. (1983). College choice in America. Cambridge, MA: Harvard University Press.

Morgan, S. L. (2005). On the edge of commitment: Educational attainment and race in the United States. Stanford, CA: Stanford University Press.

Munro, B. H. (1981). Dropouts from higher education: Path analysis of a national sample. American Educational Research Journal, 18(2), 133-141. doi:10.3102/00028312018002133

Pascarella, E. T., Pierson, C. T., Wolniak, G. C., \& Terenzini, P. T. (2004). First-generation college students: Additional evidence on college experiences and outcomes. Journal of Higher Education, 75(3), 249-284. doi:10.1080/00221546.2004. 11772256

Pascarella, E. T., \& Terenzini, P. T. (1980). Predicting freshman persistence and voluntary dropout decisions from a theoretical model. The Journal of Higher Education, 51(1), 60-75. doi:10. $2307 / 1981125$

Pearson, W. (2004). Supporting adult student persistence to the baccalaureate degree. The Journal of Continuing Higher Education, 52(2), 23-36. doi:10.1080/07377366.2004. 10400282

Pusztai, G. (2011). Schools and communities of norm-awareness. Religions, 2(3), 372-388. doi:10.3390/rel2030372

Tinto, V. (1993). Leaving college. Chicago, IL: University of Chicago Press.

Wardley, L. J., Bélanger, C. H., \& Leonard, V. M. (2013). Institutional commitment of traditional and non-traditional-aged students: A potential brand measurement? Journal of Marketing for Higher Education, 23(1), 90-112. doi:10.1080/ 08841241.2013 .810691 